\title{
SOME AMERICAN PLANTS CONSIDERED AS SOURCES OF VITAMINES, AND AS PARTS OF A DIET FAVORABLE TO THE PRESERVATION OF THE TEETH ${ }^{1}$
}

\author{
J. F. MCCLENDON
}

Physiological Laboratory of the University of Minnesota Medical School, Minneapolis, Minn.

CONTENTS

I. Introduction.

II. Lists of American plants..................................... 282

List No. 1. Some North American plants that were used as food, or taken internally as medicine, by North American Indians; including some materials that were "chewed" and their vitamines swallowed ................ 282

List No. 2. Some tropical American plants that were cultivated by North American Indians, or are suitable articles of commerce from the standpoint of content of vitamines............................... 291

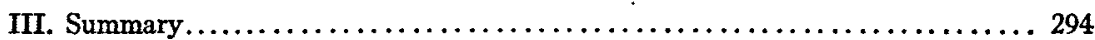

IV. Bibliography ....................................... 295

\section{INTRODUCTION}

It seems evident, from data compiled by Pickerill, that savage races have very good teeth, whereas about 95 percent of the number of civilized persons have dental caries; and also that this condition is not due to heredity, since the change in the teeth follows the process of civilization, no matter how rapidly this process is effected. That diet has something to do with tooth preservation seems probable, since a pyorrhea-like affection is characteristic of scurvy and the teeth become imperfect as a result of rickets. Dr. Edwin F. Robb, ${ }^{2}$ working in my laboratory, has shown that in scurvy the calcium stores of the body are depleted, and that much calcium passes out in the urine. The bones dissolve by enlargement of the marrow cavities. I have found osteodentine in the pulp cavity in scurvy. ${ }^{2}$

1 This paper was received for publication on August 29, 1920, and is one of many available papers that we have not been able to publish promptly. This paper was referred to, in the last preceding issue, as due for publication in this number (McClendon and collaborators: Journal of Dental Research, 1921, iii, p. 40).-ED.

2 Robb, McClendon, and collaborators: Journal of Dental Research, 1921, iii, p. 39. 
Until we know more about the nature and causes of the "deficiency" diseases, we cannot determine how prevalent they are. Many ill defined illnesses may be incipient cases of "deficiency" diseases. With the possible exception of pellagra (and related diseases, such as acrodynia), which seems to depend on protein deficiency, all the "deficiency" diseases appear to be due to lack of some chemical substance of unknown composition, called vitamine for lack of a better name. Durand found dental caries in a larger percentage of children that had been fed in infancy on sweetened condensed milk, than in children that had been breast fed. Condensed milk has a low vitamine content, due to partial destruction of vitamines by heat and to dilution of vitamines with a vitamine-free substance, sugar.

It seems very probable that, if we knew all the foods eaten by savage races and ate them in the amounts eaten by savages, the incidence of dental caries would be greatly decreased. This opinion specially includes the diet of the infant during the period when the teeth are developing. Since savages had practically no "artificial" infant food except the banana, which is said not to be indigenous to America and certainly was not to the greater part of North America, American Indians must have nursed their infants for a long period. It is said that the Fijians nursed their infants three years and gave them bananas and other things in addition. It seems necessary to conclude that the infants of American Indians could not have survived if the period of nursing had not been as long as that.

Ethno-botanists list a number of plants that were and are eaten by children of American Indians. While the papoose was not allowed to crawl around, it must have been dependent on what was given to it. I have seen mothers chew food until it was soft and then give it to infants to eat. This method of feeding was probably common among savages. The fact that some infants, that have been breast fed for three years, are undernourished, does not indicate the presence of deleterious substance in the milk, but rather an insufficiency of some substance that could be supplied by the suitable addition of other food, without the necessity for weaning.

I had occasion to make observations of the diet and teeth of Mexicans, during the years from 1888 to 1903, in various parts of Mexico 
and on the Mexican border. The Mexican has good teeth. The conclusion from these casual observations of the teeth of the Mexican-that they are good teeth-is corroborated by the records of the U. S. Army Draft Boards, in the contrast of the poor teeth of the general draftees with the excellent teeth of the draftees along the Mexican border that included men of Mexican descent. As to the food eaten by Mexicans: my observations, coming long after the Spanish settlers had introduced sugar-cane, peaches, oranges and other plants, do not relate to the primitive diet, but they indicate that certain accounts that have been published about that diet are misleading. Hopewell-Smith states that "the Indians of Mexico seldom employ condiments for flavoring food, which is generally simple in character and taken cold.". On the contrary, the further I travelled from railroad communication, the better flavored I found the diet of the Mexicans. When we bear in mind that yuccas and nolinas, such as Dasylerion texanum, too woody for a horse or cow to eat, are used by Mexicans for making beverages, the impression will be gained that the Mexican uses everything possible for food and drink. We now know that yeast is a rich source of watersoluble vitamine. The Mexicans imbibed cultures of wild yeast in the fermented pulque, sotol, and other drinks. It was only after the advent of the white man that these nutritious drinks were distilled to form the mescal, tequila, and sotol aquardiente, that have largely replaced the former.

Besides eating food from nearly every phylum of the animal and plant kingdoms, the Indians imbibed a large number of drinks made by extracting plants with hot or cold water and hence containing water-soluble vitamines. Since the North American Indians seem to be the best known in this regard, a (partial) list of the plants they used is given below, followed by a list of tropical American plants that have found their way into the United States and may have done so occasionally in pre-Columbian days. Some of these plants were cultivated by North American Indians, especially corn, beans, pumpkins and squashes. Since it is immaterial from a nutritional standpoint whether vitamines are taken as food or medicine, these two groups of plants are not separated in the appended lists (1 and 2). 


\section{IISTS OF AMERICAN PLANTS}

List No. 1. Some North American plants that were used as food, or taken internally as medicine, by North American Indians; including some materials that were "chewed" and their vitamines swallowed

Abronia fragrans (sand puff)

Acanthocheton wrightii (herb, ancient Hopi food)

Acer negundo, saccharum, saccharinum and rubrum [maple (sugar)]

Achillea millefolium (yarrow)

Acornus calamus (sweet flag)

Actinella odorata (herb)

Adenostegia (yumayut)

Agaricus campester and arvensis (mushroom)

Agastache anetheodora (anise)

Agave americana, parryi, palmeri, wislizeni, and deserti (maguey, pulque plant)

Agrostis perennaus (grass)

Alectoria jubata and fremontii (lichen)

Allionia nyctaginea (four-o-clock)

Allium bisceptrum, acuminatum, mutabile, recurvatum, and cernuum (wild onion)

Amanita rubescens (mushroom)

Amaranthus blitoides, torreyi and retroflexus (tumbleweed)

Ambrosia elatior and artemisiaefolia (ragweed)

Amelanchia alnifolia (June berry, service berry)

Ammobroma sonorae (sand food)

Amoreuxia wrightii, and palmatifida (sayas, indian parsnip)

Amorpha canensens (shoestring)

Amsinckia tessellata (herb)

Andropogon furcatus (red hay)

Anemone canàdensis and cylindrica (wind flower)

Angelica (angelica)

Anhalonium engelmanni, fissuratum and lewini (cactus, peyote)

Aphlopappus (herb)

Aphyllon fasciculatum (cancer root)

Apios apios, and tuberosa (ground nut)

Aquillegia coerulea, and canadensis (wild columbine)

Arctostaphylos manzanita, patula, glauca and tomentosa (manzanita)

Arisaema triphyllum (indian turnip)

Armillaria mellea (honey mushroom) 
Artemisia biennis, discolor, trifida, dracunculiodes, tridentata, frigida, gnaphalodes, forwoodii, filifolia, wrightii, and heterophylla (wild sage, fuzzy weed, wormwood)

Asclepias tuberosa, exaltata, syriaca, verticillata, erosa, speciosa, eriocarpa, galioides, and involucrata (butterfly weed, milkweed)

Asclepiodora decumbens (milkweed)

Asimina triloba (North American pawpaw)

Aster hesperius (wild aster)

Astragalus caroliniana, pictus filifolius and diphysus (rattle pod, milk vetch)

Atriplex canescens, confertifolia, argenteum and powellii (arache)

Avena fatua (wild oats)

Bahia woodhouseii [(purgative) thistle]

Balsamorrhiza sagittata (arrow root)

Barbarea barbarea, stricta and præcox (scurvy grass)

Bechmannia erucaeformis (slew grass)

Berberis canadensis, repens, aquilifolium and trifoliata (barberry, Oregon grape)

Betula lenta, and fontinalis (birch)

Bidens bigelovii (bur marigold)

Bigelovia douglasii and parishii (rabbit bush)

Blennosperma californicum (weed)

Bloomeria aurea (lilly)

Boletus versipellis and edulis (mushroom, cepe)

Bovista plumbea (puff ball)

Brickellia grandiflora and wrightii (herb)

Brodiaea congesta, capitata and volubilis (purple-flowered grass-nut, climbing grass-nut, wild hyacinth)

Bromus breviaristatus and maximus (brome grass)

Cactus viviparus, heyderi and goodrichii (cactus)

Calandrinia cawlescens (red maids)

Calla palustris (water arum)

Calliproa lutea (yellow-blossom grass-nut)

Callirrhoe involucrata, digitata and pedata (mallow)

Calochortus nutallii, macrocarpus and aureus (mariposa lilly, sego)

Calvatia cyathiformis, and gigantea (puff ball)

Camassia esculenta (camos)

Cantharellus cibarius (mushroom)

Carduus ochrocentris (thistle)

Carex utriculata (sedge) 
Carcum gairdnerii, kelloggii and oregonum (yamp, wild anise)

Castanea dentalla and pumila (chestnut)

Castanopsis chrysophilla (Oregon chinquapin)

Castilleia parviflora (painted cup)

Caulophyllium thalictroides (blue cohosh)

Ceanothus americanus (red root, New Jersey tea)

Celtis occidentalis and reticulata (hackberry)

Cercocarpus montanus (mountain mahogany)

Cereus giganteus, thurberi, stramineus and triangularis (giant cactus)

Chamaesaracha coronopus (benedictine berry)

Chamaesyce serphylliflora (milkweed)

Chenopodium capitatum, leptophyllum, rubrum, cornutum, fremontii, californicum and album (lambsquarters, pigweed)

Chlorogalum pomeridianum, parviflorum and divaricatum (little soaproot, wild potato)

Chrysopsis villosus (golden aster)

Cinna arundinacia (wood reed-grass)

Citrullus citrullus (watermelon)

Clavaria flava and fusiformis (coral mushroom)

Claytonia caroliniana, virginica, megarrhiza, and perfoliata (wild lettuce, spring beauty)

Clematis lingusticifolia (virgin's bower)

Cleome integrifolia (stinking clover)

Clitopilus aboritivus (mushroom)

Cnicus drummondi, undulatus and edulis (thistle)

Collybia velutipes and radicata (mushroom)

Coprinus comatus, micaceus and a tramentarius (shaggy-mane mushroom, glistening coprinus, inky coprinus)

Coreopsis cardaminefolia (coreopsis)

Coriandrum sativum (coriander)

Corylus americana and californica (hazelnut)

Cowania mexicana (cliff rose)

Crataegus chrysocarpa (red haw)

Cripis glauca (hawk's beard)

Croton texensis, corymbulosus (croton, chapparal tea)

Cucurbita ficifolia, and foetidissima (gourd)

Cyclobothra (beaver-tail grass-nut)

Cycloloma atriphicifolium (winged pigweed)

Cymoterus longipes, montanus, globosus, glomeratus, fendleri and purpureus (chimaja) 
Cyperus esculentus and rotundus (chufa, nut grass)

Dalea lanata (herb)

Dasylerion texanum (sotol)

Dasystephana puberula (gentian)

Datura meteloides and quercifolia (jimson weed)

Deschampsia caespitosa (hair grass)

Dichoria brandegii (katokia)

Diospyros virginiana and texana (persimmon)

Dithyraea wislizeni (spectacle pod)

Dracocephalum parvillorum (mint)

Echeveris lanceolata (rock lettuce)

Echinocactus visnaga and wislizeni (cactus)

Echinocystis macrocarpa (chillicothe)

Elaegnus argentea (silver berry)

Elymus canadensis and condensatus (wild rye)

Ephedra nevadensis and antisyphilitica (teamster's tea, joint fir)

Epilobium coloratum (willow herb, fireweed)

Equisetum laevigatum (horsetail)

Eriocoma membranacea and cuspidata (grass)

Eriodictyon tomentosum and parryi (yerba santa)

Eriogonum ovalifolium, corymbosum, alatum, fasciculatum and jamesii (medicine root)

Eryngium aquaticum (button snakeroot)

Erythraea venusta (canchalagua)

Erythronium albidum and mesochoreum (spring lilly)

Escholtzia californica (California poppy)

Euonymus atropurpurea (burning bush)

Euphorbia serphyllifolia and polycarpa (spurge)

Euretia lanata (white sage)

Falcata comosa (ground bean, hog peanut)

Ferula multifida (totuv)

Festuca ovina (sheep's fescue-grass)

Fistulina hepatica (beef-tongue mushroom)

Fragaria vesca, americana and virginiana (strawberry)

Fritillaria atropurpurea and pudica (lilly)

Gaertneria acanthicarpa (ragweed)

Galium (bedstraw)

Gaultheria procumbens (wintergreen)

Gaura parviflora (herb)

Gaylusacia (huckleberry) 
Geranium fremontii (cranesbill)

Geum macrophyllum (herb)

Gilia aggregata and staminea (standing cypress)

Glyceria distans (manna grass)

Glycine apios (indian potato)

Glycyrrhiza lepidota (licorice)

Grindelia squarrosa (sticky head)

Grossularia missouriensis (gooseberry)

Gutierrezia euthamniae, filifolia and longifolia (broom weed, snake weed)

Gymnolemia multiflora (herb)

Hedeoma hispida and drummundii (pennyroyal)

Hedysarum mackenzii (legume)

Helianthus annuus, tuberosus, doronicoides, and giganteus (sunflower, Jerusalem artichoke)

Heracleum lanatum (cow parsnip)

Hesperocallis undulata (desert day-lilly)

Hesperoscordium lacteum (white-flowered grass nut)

Heteromeles arbutifolia (christmas-berry)

Heuchera pubescens (alum root, rock geranium)

Hicoria ovata (hicory nut)

Houttuynia californica (yerba mansa)

Humulus americana (hops)

Hydnum coralloides, laciniatum and erinaceus (coral mushroom)

Hymenopappus filifolius (thistle)

Hymenoxys floribunda (Colorado rubber-plant)

Ilex vomitoria (cassine)

Ionoxalis violacea (sheep sorrel)

Iva axillaris (marsh elder)

Juglans nigra and cinera (black walnut, butternut)

Juniperus californica, virginiana, occidentalis, pachyphloea, mexicana and monosperma (cedar, juniper)

Kalmia glauca (pale laurel)

Kryntzkia sericea (herb)

Kunzia tridentata (shrub)

Laciniaria scariosa and punctata (blazing star)

Lactarius deliciosus (orange milk-mushroom)

Lactuca pulchella (blue-lettuce)

Lathyrus (pea)

Layia glandulosa (tidy-tips)

Ledum palustre and groenlandicum (marsh-tea, labrador-tea) 
Lepargyrea argentea (buffalo-berry)

Lepidium nitidum (peppergrass)

Lepiota procera (parasol mushroom)

Leucelene ericoides (thistle)

Lewisia rediviva and brachycalyx (bitter-root)

Lilium umbellatum (lilly)

Lindera benzoin (spice-bush)

Linum lewisii, rigidum and puberulum (flax)

Lithospermum pilosum, multiflorum and canencens (puccoon)

Lonicera conjugialis (Oregon cranberry)

Lophanthus urticifolius (mint)

Lophophora williamsii (cactus)

Lotus strigosus (tovinal)

Lupinus littoralis (lupine)

Lycium pallidum (tomatillo)

Lycoperdon gemmatum, piriforme, and solidum (puff ball, indian bread)

Lygodesmia juncea and grandiflora (skeleton weed)

Madaria (tar weed)

Madia glomerata (tar weed)

Malacothrix californica (makiyal)

Malus ioensis (crabapple)

Malvastrum coccineum (red false-mallow)

Mammilaria (ball cactus)

Marasmius oreades, scorodonius and rotula (fairy-ring mushroom, garlic. mushroom, little-wheel mushroom)

Martynea louisiana (unicorn plant)

Medeola virginiana (indian cucumber-root)

Melica (melic grass)

Mentha canadensis (mint)

Mentzelia albicaulis (herb, stick leaf)

Mesembryanthemum aequilaterale (fig marigold)

Micromeria douglassii (yerba buena)

Microseris nutans (succulent root)

Mimulus luteus (mask flower)

Mirabilis californica (herb)

Mitchella repeus (partridge berry)

Mitella trifida (bishop's cap)

Monarda fistulosa and citriodora (horsemint)

Monardella lanceolata (indian tea)

Montia perfoliata (indian lettuce) 
Morchella esculenta, deliciosa, conica and semi-libera (morel)

Muscadinia munsoniana and rotindifolia (bullace grape, muscadine, scuppernong)

Myrica asplenifolia (sweet fern)

Nelumbo lutea (yellow lotus, water chinquapin)

Nymphaea polysepala and advena (yellow pond-lilly)

Oenothera biennis and caespitosa (evening primrose)

Opuntia rutila, polyacantha, humifusa, tuna, ficus-indica, engelmannii, vulgaris, arborescens, camanchica and whipplei (prickly-pear, cane cactus)

Orobanche tuberosa (cancer root)

Orogenia linearifolia (wild parsnip)

Orontium aquaticum (golden club)

Oxycoccus macrocarpus (cranberry)

Padus nana and melanocarpa (chokecherry)

Panicularia fluitans (sugar grass)

Panicum obtusum and capillare (old-witch grass)

Parmelia saxicola (lichen)

Parosela aurea and lasianthera (bitter medicine)

Passiflora incarnata (maypop)

Pectis angustifolia and papposa [thistle family]

Pellaea omithopus (tea fern)

Peltandra virginica and sagittaefolia (arrow arum)

Pentstemum grandiflorus (fox glove)

Peritoma serrulatum (rocky-mountain bee-plant)

Petalostemum purpureum (purple clover)

Peucidanum graveolens, canbyi, eurycarpum, farinosum, geyeri, and ambiguum (biscuit root)

Phacelia ramosissima (sikimona)

Philibertia beterophylla (milkweed)

Pholiota praecox and caperata (mushroom)

Phorandendron juniperium (mistletoe)

Photinea arbutifolia (California holly)

Phragmites phragmites (cane grass)

Physalis neomexicana, fendlerii, longifolia, heterophylla and lanceolata (ground cherry)

Physaria newberryi (hohoyana)

Pinus edulis, monophylla, cembroides, ponderosa, lambertiana, sabiniana and murrayana (pine nut, piñon, sugar pins)

Pleurotus ulmarius, ostreatus (mushroom, oyster mushroom) 
Poa californica (meadow grass)

Podophyllum peltatum (may apple)

Polygonum ramosissimum, douglasii and lapathifolium (smartweed)

Polyporus applanatus and frondosus (tree fungus)

Polystictus versicolor and perennis (bracket fungus, mushroom)

Populus sargentii and tremuloides (cottonwood, aspen)

Portulaca retusa and oleracea (purslane)

Promus virens (grass)

Prosopis juliflora and pubescens (mesquite, screw bean)

Prunus demissa, americana, besseyi, nigra, angustifolia, subcorticata, ilicifolia and hortulana (plum)

Pseudotșeuga douglassii (douglass spruce)

Psoralea esculenta, tenuifora, hypogaea, californica, castorea, canescens, orbicularis and subacaulis (tipsin, indian potato)

Pteris aquilina (brake)

Quamasia quamash (camos)

Quamoclidion multiflorum (wild four-o-clock)

Quercus undulata, macrocarpa, rubra, garryana, lobata, virginiana, pungens, oblongifolia, engelmannii, michauxii, prinoides, agrifolia, gambelii, douglasii, californica, chrysolepsis, wizlizeni, dumosa (oak)

Ramona stachyoides and polystachya (black sage and white sage)

Ramunculus aquatilis, cymbalaria and californicus (crow foot)

Ratibida columaris (cone flower)

Reverchonia arenaria (patanwuba)

Rhamnus purschiana (cascara sagrada)

Rhus trilobata, aromatica, glabra, toxicodendron, hirta, copallina, integrifolia and ovata (sumac and poison ivy)

Ribes aureum, divaricatum, lacustre, leptanthum, oxyacanthoides, americanum, cereum and inebrians (currant)

Rosa californica, fedlerii, pratincola and nutcana (wild rose)

Rubus leucodermis, nutkanus, occidentalis, stragosus parviflorus and vitifolius (raspberry, blackberry)

Rumex hymenosepalus, geyerii, salicifolius and mexicanus (dock)

Russula virescens (mushroom)

Sabal palmetto (palmetto)

Saccharomyces (yeast)

Sagittaria latifolia and arifolia (arrowleaf)

Salicornia herbacea (brittlewort)

Salvia polystachya, columbariae, carduacea, tiliaefolia, ballatæflora (sage, chia) 
Sambucus racemosa, glauca and canadensis (elderberry)

Sanicula tuberosa (turkey pea, snakeroot)

Sassafras officinale (sassafras)

Sidalcea malvaeflora (wild hollyhock)

Scirpus lacustris and validus (bulrush)

Scutellaria (skullcap)

Senecio (squaw weed)

Sericotheca dumosa (a small, round fruit)

Sheperdia argentea and canadensis (bullberry, soapberry)

Silene acaulis, multicaulis and scouleri (catchfly)

Silphium perfoliatum, laciniatum (cup plant, pilot weed)

Sisymbrium canescens and incisum (hedge mustard)

Sisyrinchium bellum (blue-eyed grass)

Sium cicutaefolium (herb)

Smilax herbacea, pseudo-china, bona nox, glauca, rotundifolia and auriculatum (Jacob's ladder)

Solanum jamesii, elaegnifolium, fendlerii, triflorum, douglasii and rostratum (nettle, buffalo bur, native potato, nightshade)

Solidago canadensis, nemoralis, spectabilis, missouriensis and odora (goldenrod)

Sonchus asper (saw thistle)

Sophia (tansy mustard)

Sophora secundifolia (frijolillo)

Sparassis herbstii (mushroom)

Sparganium eurycarpum (bur reed)

Spathyema foetida (polecat weed)

Sphaeralcea angustifolia, and incana (mallow)

Spiraea caespitosa (spiraea)

Sporobolus cryptandrus (rush grass)

Stachys palustris (wound wort)

Stanleya albescens (wild mustard)

Stanleyella wrightii (wild mustard)

Suaeda depressa (sea blite)

Talinum aurantiacum (herb)

Thelesperma gracile and trifidum (indian tea)

Townsendia arizonica (herb)

Tricholoma equestre (mushroom)

Trifolium ciliolatum, gracilentum, microsephalum, tridentatum, obtusiflorum and other species (clover)

Triglochin maritimum (arrow-grass) 
Tripterocalyx wootonii [four-o-clock family]

Trisetum subspicatum (grass)

Triticum vulvage (plant)

Troximon aurantiacum (indian water-cress)

Typha latifolia (cattail)

Ulmus fulva (slippery elm)

Ustilago maydis or zeae (corn smut)

Vaccinium caespitosum, membranaceum, scoparium and many other species (blue-berry, bilberry)

Vagnera amplexicaulis (false solomon's-seal)

Valeriana adulis (kooyah)

Verbena hastata (verbena)

Viburnum lentago (black-haw)

Viola cucullata and pedunculata (violet)

Vitis arizonica, labrusca, rupestris, girdiana, monticola, cordifolai, bicolor, candicans and other species (wild grape, fox grape, sugar grape, mustang grape)

Washingtonia longistaylis (sweet cicely)

Woodwardia radicans (brake fern)

Wyethia amplexicaulis (succulent root)

Xanthium commune (cocklebur)

Xanthoxalis stricta (sourgrass)

Ximenesia exauriculata (crownbeard)

Yucca baccata, macrocarpa, treculeans, schottii, whipplei, mohavensis and glauca (yucca, soapweed, spanish bayonet)

Zizania aquatica (wild rice)

Zygadenus nuttalli (lilly)

List No. 2. Some tropical American plants that were cultivated by North American Indians, or are suitable articles of commerce from the standpoint of content of vitamines

Achras sapota (chewing-gum tree, sapodilla)

Ananas ananas (pineapple)

Anona cherimolia, reticulata, muricata, and squamosa (cherimoya, custard apple, sour sop and sweet sop)

Arachis hypognea (peanut)

Batatas batatas (sweet potato)

Bertholletia excelsa (brazil nut)

Brosimum alicastrum (bread nut) 
Capsicum annuum (red pepper)

Casimiroa edulis (white sapota)

Cerica papaya (papaya)

Chenopodium quinoii (quinoa)

Chrysophyllum cainito (star apple)

Coccoloba uvifera (sea grape)

Cocus nucifera (coconut)

Coumarouna odorata (tonka bean)

Cucumis angurica (gherkin)

Cucurbita pepo and maxima (pumpkin, squash)

Cryptocarya moschata (Brazilian nutmeg)

Erythroxylon coca (coca plant)

Eugenia pimenta (Jamaica pepper)

Ilex paraguayensis (mote)

Lecythis zambucayo and amoxonum (monkey pot, paradise nut)

Lucuma mammosa (lucuma)

Lycopersicon lycopersicum (tomato)

Mammea americana (mammee apple)

Manihot manihot, and palmata aipi (cassava)

Maranta arundinacea (arrowroot)

Paullinia cupana (guarana)

Pereskia aculeata (barbados gooseberry)

Persea persea (alligator pear, avocado)

Phaseolus vulgaris and lunatus (bean and lima bean)

Psidium guayaba, montanum and cattleyana (guava)

Sapota zapotilla (sapodilla)

Smilax officinalis, papyracea and medica (sarsaparilla)

Solanum tuberosum, muricatum and melongena (potato, melon-pear and eggplant)

Theobroma cacao (chocolate tree)

Tropaeolum, majus and minus (nasturtium)

Vanilla planifolia, grandiflora and aromatica (vanilla)

Zamia integrifolia and furfuracea (Florida arrowroot, sago).

Zea mays (indian corn)

The foregoing lists contain some plants, such as Datura and poison ivy, that are poisonous, but were nevertheless taken internally and may have functioned as a source of vitamine. The Indians used Datura as an anesthetic in surgical operations and ate poison ivy in order to de-sensitize themselves. One might suppose that plants 
that were considered to be medicines were taken in such small quantities, and so infrequently, that they could not have been important sources of vitamine. The quantities varied of course, but were sometimes considerable, three pints of a decoction often having been given in two days. Diarrhea was very prevalent among the Indians and hence medication was frequent.

The supply of wild plants was by no means unlimited and the Indians are supposed to have cultivated many species. Besides the corn, beans, squashes, pumpkins and potatoes that we have obtained from the Indians, they planted other species. The watermelon is generally supposed to have come from Africa but, according to Gilmore, the Indians of the Missouri River region cultivated a small spherical variety before the introduction of the modern varieties. Indians planted Jerusalem artichokes and sunflowers, and aided in the distribution of many wild fruits and land and water plants. Whether the Indians tilled the soil in the case of the latter seems doubtful, but they are said to have protected them. The Indians of the Pacific Coast did not cultivate the soil, but they lived largely on plant food. Their habit of gathering roots resulted in the name "Digger Indian."

From the standpoint of vitamines, the mode of preparation of food is of importance. The Indian method of boiling corn in potash or lime-water may have lessened the vitamine content in the corn but, since the boiling was applied to the whole grain, probably considerable water-soluble vitamine was left in it. Corn was eaten whole after this treatment or ground while wet. Mexicans grind wet corn on the metate, but some of them take the wet corn each day to an ixtamal mill and have it ground by power. Some Indians ground the corn in the dry state. Acorns were soaked in water after grinding, a process that probably removed much of the water-soluble vitamine. The great superiortiy of the Indian method of milling was due to the fact that the germ was not removed. The germ that contains the vitamine is removed from nearly all the cereals we eat, and fed to stock. This is good for the stock, but no one has been able to prove that it is good for us.

The antiscorbutic vitamine is the most perishable and difficult to store for winter. Drying of most vegetables destroys this vita- 
mine. Only very acid foods, such as tomatoes or some fruits, have been shown to be antiscorbutic in the dry state. The Indian kept antiscorbutics for winter in the form of dried fruits and fresh foods. Not only were roots and tubers stored for winter, but such perishable things as watermelons were stored by wrapping in yucca leaves and suspending from the rafters.

The fact that Indians were well supplied with vitamine does not prove that vitamines are responsible for good teeth but suggests at least that the subject is worthy of further study. Many of the foods eaten by Indians required more mastication than ours. "Chewing" is considered bad manners by us and is discouraged in many ways. We have developed such a fear of germs that we discourage our children from "chewing" many raw plants that were "chewed" by Indians.

From consideration of the data compiled by Pickerill one might suppose that a good definition of a civilized man is a man with carious teeth. From this standpoint the Mexican is not completely civilized and we may have the opportunity of studying the process of his civilization. The difficulty in studying the question experimentally on animals is due to the fact that few animals are sufficiently civilized to develop caries, although old dogs frequently have pyorrhea.

\section{SUMMARY}

North American Indians had good teeth. This condition was probably due to complete adequacy of diet. The Indians ate a greater variety of foods than is generally supposed. Their vegetable foods were of such nature, and so preserved and prepared, as to furnish all three classes of vitamines. Since lack of vitamines causes changes in the teeth (scurvy) or improper development of the teeth (rickets), the abundance of vitamines in the diet of Indians probably had much to do with the state of their teeth. These are merely suggestions intended to stimulate research along this line. 


\section{BIBLIOGRAPHY}

\section{Ethno-botanical studies}

Ceamberdn, R. V. 1911 Memoirs of the American Anthropological Association, ii, p. 331 .

1909 American Anthropologist, xi, p. 27.

Covtce, F. V. 1897 Contributions from the U. S. National Herbarium, v, p. 87.

FEWKEs, J. W. 1896 American Anthropologist, ix, p. 14.

GruMore, M. R. 1919 Thirty-third annual report, Bureau of American Ethnology, p. 43.

Havard, v. 1895 Bulletin of the Torrey Botanical Club, xxii, p. 98.

1896 Bulletin of the Torrey Botanical Club, xxiii, p. 33.

Hovgr, W. 1897 American Anthropologist, x, p. 33.

Powers, S. 1874 Proceedings of the California Academy of Science, v, p. 373.

Robbins, W. W., Harrington, J. P., and Freire-Marreco, B. C. 1916 Bulletin 55, Bureau of American Ethnology (cites Barrows, D. P. The ethno-botany of the Coahuilla Indians of Southern California, Chicago, 1900, and Matthews, W., American Naturalist, 1886, xx, p. 767.)

Stevenson, M. C. 1915 Thirtieth annual report, Bureau of American Ethnology, p. 31.

STICKNEy, G. P. 1896 American Anthropologist, ix, p. 115.

\section{Taxonomy}

Clements, F. E., and Clements, E. S. 1913 Rocky Mountain Flowers (New York).

Coulter, J. M., AND Nelson, A. 1909 New manual of Rocky Mountain botany, New York.

Gray, AsA 1908 New manual of botany (7th ed.; New York).

Henry, J. K. 1915 Flora of Southern British Columbia (Toronto).

PIPER, C. V., ANd Beatrie, R. K. 1915 Flora of the Northwest Coast (Pullman, Wash.).

RYDBeRg, P. A. 1906 Flora of Colorado (Fort Collins, Colorado).

Swall, J. K. 1903 Flora of the Southeastern United States (New York).

\section{Popular articles}

Eaton, M. E. 1915 National Geographic Magazine, xxvii, p. 483.

1916 National Geographic Magazine, xxix, p. 584.

1919 National Geographic Magazine, xxxv, p. 168.

Grosvenor, 1917 National Geographic Magazine, xxxi, p. 481.

KRIEGER, L. C. C. 1920 National Geographic Magazine, xxxvii, p. 387.

MerRtam, C. H. 1918 National Geographic Magazine, xxxiv, p. 129.

Ward, ARTEMas 1911 The Grocer's Encyclopedia (New York).

\section{Diet in relation to teeth}

Durand, J. I. 1916 Journal of the American Medical Association, 1xvii, p. 564.

Hopewele-SMrth, A. 1913 Dental anatomy and physiology, p. 41 (London).

MelranBY, M. 1918 Lancet, cxcv, p. 767.

Pickerill, H. P. 1914 The prevention of dental caries and oral sepsis (2nd ed.; Philadelphia). 